УДК 666.974:666.973.2

Д-р техн. наук А.Н. Ефремов

\author{
A.N. Yefremov
}

\title{
АЛЮМОСИЛИКАТНЫЕ ВЯЖУЩИЕ НА ОСНОВЕ АЛЮМИНАТА НАТРИЯ
}

\section{ALUMINOSILICATE BINDERS ON THE BASIS OF ALUMINATE OF SODIUM}

Исследованиям щелочных вяжущих системы $\mathrm{Na}_{2} \mathrm{O}-\mathrm{Al}_{2} \mathrm{O}_{3}-\mathrm{SiO}_{2}-\mathrm{H}_{2} \mathrm{O}$ в последние годы уделяется пристальное внимание как у нас в стране, так и за рубежом. Их структурообразующим соединением являются гидроалюмосиликаты типа $\mathrm{Na}_{2} \mathrm{O} \cdot \mathrm{Al}_{2} \mathrm{O}_{3} \cdot(2-4) \mathrm{SiO}_{2} \cdot \mathrm{nH}_{2} \mathrm{O}$. В качестве основных компонентов вяжущих Глуховским В.Д. впервые предложены каолин и огнеупорные глины, предварительно обожженные до температуры $800-1000^{\circ} \mathrm{C}$ [1]. На их основе при затворении растворами едких щелочей и метасиликата натрия можно получить щелочные вяжущие активностью 10-80 МПа [1]. Позже в ряде работ отечественных и зарубежных ученых щелочные вяжущие на основе термоактивированного каолина, основой которых является метакаолинит, стали называть геополимерами (геополимерными цементами), а термоактивированный каолин - метакаолином [2, 3].

С точки зрения применения при высоких температурах такие вяжущие характеризуются рядом недостатков: продукты дегидратации гидроалюмосиликатов имеют низкую огнеупорность и высокую усадку, особенно огневую [2], вследствие летучести щелочного оксида нестабильны в условиях восстановительной среды и др. Кроме того, в составе перечисленных алюмосиликатных компонентов и низкомодульных силикатов натрия в состав вяжущих вводится значительное кличество кремнезема, который снижает температуру плавления многих огнеупорных систем.

Синтез щелочных гидроалюмосиликатов возможен при замене гидроксида и низкомодульных силикатов натрия алюминатом натрия. На возможность получения щелочных связок синтезом щелочных гидроалюмосиликатов из смесей концентрированных растворов алюминатов впервые указал Глуховский В.Д. [1]. Будников П.П. и Петровых И.М. [4] синтезировали кристаллический цеолит типа $\mathrm{Na}_{2} \mathrm{O} \cdot \mathrm{Al}_{2} \mathrm{O}_{3} \cdot 2 \mathrm{SiO}_{2} \cdot \mathrm{nH}_{2} \mathrm{O}$, используя в качестве исходных компонентов алюминат натрия со щелочным модулем 
$\left[\mathrm{Na}_{2} \mathrm{O}\right] /\left[\mathrm{Al}_{2} \mathrm{O}_{3}\right]=1,8$ и жидкое стекло с силикатным модулем $\left[\mathrm{SiO}_{2}\right] /\left[\mathrm{Na}_{2} \mathrm{O}\right]=3,1$. В работе [5] показано, что алюминат натрия состава $(1,1-1,5) \quad \mathrm{Na}_{2} \mathrm{O} \cdot \mathrm{Al}_{2} \mathrm{O}_{3}$ является активным инициатором гидратации высококремнеземистого алюмосиликатного стекла - перлита. При этом получены водостойкие вяжущие автоклавного твердения активностью 11-71 МПа, структурообразующими соединениями которых являются низкоосновные цеолиты типа анальцима - $\mathrm{Na}_{2} \mathrm{O} \cdot \mathrm{Al}_{2} \mathrm{O}_{3} \cdot 4 \mathrm{SiO}_{2} \cdot 2 \mathrm{H}_{2} \mathrm{O}$ и натролита $-\mathrm{Na}_{2} \mathrm{O} \cdot \mathrm{Al}_{2} \mathrm{O}_{3} \cdot 3 \mathrm{SiO}_{2} \cdot 2 \mathrm{H}_{2} \mathrm{O}$.

Известно [6], что в результате спекания каолинитовых глин в шамот при температуре выше $1350^{\circ} \mathrm{C}$ значительное количество избыточного кремнезема и плавней после кристаллизации муллита переходят в расплав, который после охлаждения образует 40-60\% кремнеземистого стекла. Поэтому можно предположить, что при затворении шамотного порошка водным раствором алюмината натрия будет происходить растворение кремнеземистого стекла шамота и синтез щелочных гидроалюмосиликатов.

Замена силиката алюминатом натрия позволит увеличить огнеупорность вяжущего за счет того, что щелочной компонент не будет сокращать содержание $\mathrm{Al}_{2} \mathrm{O}_{3} . \quad \mathrm{K}$ тому же, в отличие от жидкостекольных вяжущих, где тонкомолотый шамот и шамотные заполнители остаются практически инертными по отношению к жидкому стеклу, в композициях с алюминатом натрия они будут играть активную структурообразующую роль, что повысит адгезию и сбалансирует работу связки и заполнителей.

Кроме того, обязательным компонентом большинства огнеупорных алюмосиликатных бетонов с низким и особонизким содержанием высокоглиноземистого цемента является ультрадисперсный аморфный кремнезем, конденсирующийся при выплавке ферросплавов. Высокая пуццолановая активность аморфного микрокремнезема в высокопрочных общестроительных бетонах доказана работами Батракова В.Г., Каприелова С.С., Шейнфельда А.В. [7]. Аморфный микрокремнезем должен проявлять еще более высокую активность по отношению к алюминату натрия, чем аморфный кремнезем тонкомолотого шамота. Это может обеспечить синтез щелочных гидроалюмосиликатов при более низких температурах.

В работе [8] нами показано, что применение огнеупорных и высокоогнупорных наполнителей способствует получению при температурах выше $600^{\circ} \mathrm{C}$ керамической кристаллической связки из огнеупорных фаз - муллита, корунда, алюмината натрия и $\beta$-глинозема. Поэтому целью настоящей работы являлась разработка композиций огнеупорных вяжущих на основе раствора алюмината натрия, дисперсных шамота и аморфного микрокремнезема, активных по отношению к алюминату натрия, и высокоогнеупорных муллитокорундовых и корондовых наполнителей, образующих при высоких температурах огнеупорную вяжущую матрицу бетонов.

Свойства камня вяжущих исследовались на образцах кубах с ребром 2 см, изготовленных из смесей нормальной густоты. В качестве исходных материалов использовались порошки (остаток на сите 008 5-10\%) шамота, муллитокорунда и корунда с содержанием глинозема соответственно 28,76-42,20, 92,2 и 96,8\%.

Из технологии глинозема, по методу Байера, известно [9], что при минимальном содержании $\mathrm{Na}_{2} \mathrm{O}$ алюминатные растворы при атмосферном давлении характеризуются низкой стойкостью и из них в осадок может выпадать $\mathrm{Al}(\mathrm{OH})_{3}$ в виде гидроаргиллита. При обычной температуре удовлетворительную стойкость имеют растворы со щелочным

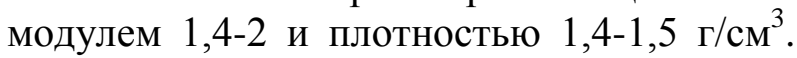
Поэтому в исследованиях использовались 
растворы алюминатов натрия плотностью

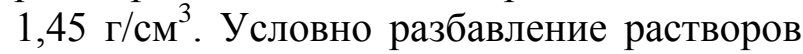
до более низкой плотности производилось введением расчетного количества воды непосредственно при затворении смесей.

Растворимость аморфного кремнезема определяется также температурой и показателем рН жидкой фазы [10]. Поэтому можно полагать, что основными факторами, определяющими синтез щелочных гидроалюмосиликатов в результате взаимодействия кремнеземистого стекла шамота и алюмината натрия, будут щелочной модуль и плотность раствора последнего, а также температура тепловлажностного твердения. Для оптимизации указанных характеристик раствора алюмината натрия по прочности пропаренных $\left(\mathrm{Y}_{1}\right)$ и автоклавированных $\left(\mathrm{y}_{2}\right)$ образцов был использован двухфакторный план эксперимента на трехчисленных уровнях $(-1 ; 0 ;+1)$. В табл. 1 и 2 представлены значения варьируемых факторов и результаты эксперимента.

Таблица 1

Значения факторов варьирования

\begin{tabular}{|c|c|c|c|c|c|c|}
\hline \multirow{2}{*}{$\begin{array}{l}\text { Код фак- } \\
\text { тора }\end{array}$} & \multirow{2}{*}{$\begin{array}{c}\text { Физический смысл } \\
\text { фактора }\end{array}$} & \multirow{2}{*}{$\begin{array}{c}\text { Единица } \\
\text { измерения }\end{array}$} & \multirow{2}{*}{$\begin{array}{c}\text { Интервал } \\
\text { варьирования }\end{array}$} & \multicolumn{3}{|c|}{ Уровни фактора } \\
\hline & & & & -1 & 0 & +1 \\
\hline $\mathrm{X}_{1}$ & $\begin{array}{l}\text { Щелочной модуль } \\
\text { алюмината натрия }\end{array}$ & - & 0,3 & 1,4 & 1,7 & 2,0 \\
\hline$X_{2}$ & $\begin{array}{l}\text { Плотность раствора } \\
\text { алюмината натрия }\end{array}$ & $\Gamma / \mathrm{cm}^{3}$ & 0,1 & 1,2 & 1,3 & 1,4 \\
\hline
\end{tabular}

Таблица 2

Матрица планирования и результаты эксперимента

\begin{tabular}{|c|c|c|c|c|c|c|}
\hline \multirow{3}{*}{ № опыта } & \multicolumn{4}{|c|}{ Значение факторов } & \multirow{2}{*}{\multicolumn{2}{|c|}{$\begin{array}{c}\text { Значение параметров } \\
\text { оптимизации }\end{array}$}} \\
\hline & \multicolumn{2}{|c|}{ кодированные } & \multicolumn{2}{|c|}{ натуральные } & & \\
\hline & $\mathrm{x}_{1}$ & $\mathrm{x}_{2}$ & $\mathrm{X}_{1}$ & $\mathrm{X}_{2}$ & $\overline{\mathrm{y}}_{1}, \mathrm{M \Pi а}$ & $\overline{\mathrm{y}}_{2}, \mathrm{M \Pi а}$ \\
\hline 1 & 2 & 3 & 4 & 5 & 6 & 7 \\
\hline 1 & -1 & -1 & 1,4 & 1,2 & 1,8 & 7,6 \\
\hline 2 & -1 & 0 & 1,4 & 1,3 & 9,5 & 39,7 \\
\hline 3 & -1 & 1 & 1,4 & 1,4 & 14,2 & 54,3 \\
\hline 4 & 0 & -1 & 1,7 & 1,2 & 2,8 & 17,0 \\
\hline 5 & 0 & 0 & 1,7 & 1,3 & 15,0 & 68,6 \\
\hline 6 & 0 & 1 & 1,7 & 1,4 & 26,5 & 85,0 \\
\hline 7 & 1 & -1 & 2,0 & 1,2 & 5,6 & 19,6 \\
\hline 1 & 2 & 3 & 4 & 5 & 6 & 7 \\
\hline 8 & 1 & 0 & 2,0 & 1,3 & 21,4 & 73,8 \\
\hline 9 & 1 & 1 & 2,0 & 1,4 & 29,8 & 91,5 \\
\hline
\end{tabular}

В результате статистической обработки данных эксперимента в соответствии с принципами математического планирования и статистической обработки [11] получены математические модели зависимости активности шамотных вяжущих от щелочного модуля и плотности раствора алюмината натрия в виде следующих полиномов второй степени: 


$$
\begin{aligned}
& y_{1}=16,04+5,15 \cdot X_{1}+9,98 \cdot X_{2}+2,85 \cdot X_{1} \cdot X_{2}-1,12 \cdot X_{1}^{2}-1,92 \cdot X_{2}{ }^{2} \\
& Y_{2}=66,78+13,88 \cdot X_{1}+31,1 \cdot X_{2}+6,3 \cdot X_{1} \cdot X_{2}-9,12 \cdot X_{1}^{2}-14,87 \cdot X_{2}{ }^{2}
\end{aligned}
$$

Информационная способность моделей проверена по критерию Фишера. Коэффициент множественной корреляции составил 0,97 и 0,96 .

На рис. 1 представлены зависимости изолиний предела прочности вяжущих при сжатии от характеристик раствора алюмината натрия. Согласно этим данным при принятой температуре тепловлажностной обработки активность вяжущих возрастает с увеличением щелочного модуля и плотности раствора алюмината натрия. Однако при переработке бокситов в промышленных условиях получают алюминаты натрия со щелочным модулем 1,7-1,8. Стойкость растворов с более низким щелочным модулем при всех концентрациях и температурах резко снижается [9]. a)

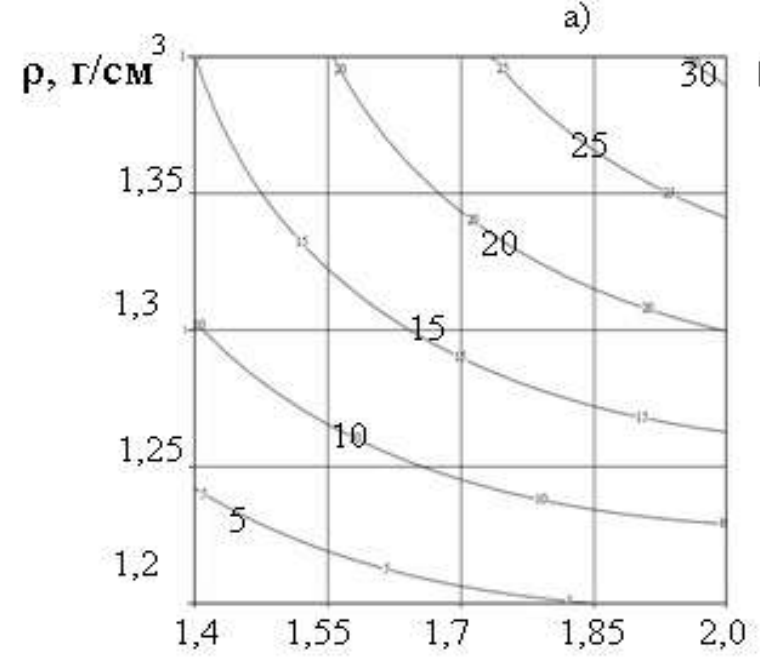

6)

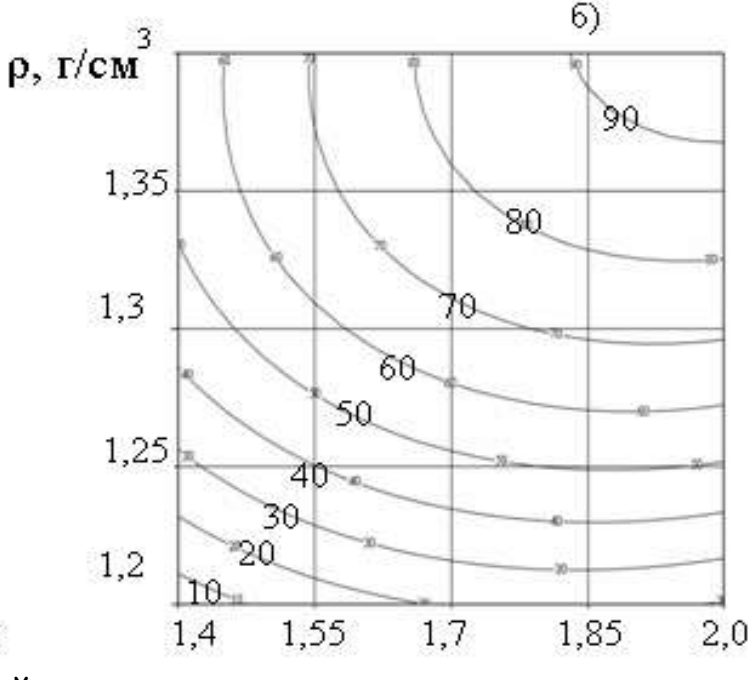

Щелочной модуль

Рис. 1. Зависимость предела прочности при сжатии, МПа, камня шамотного вяжущего после пропаривания (а) и автоклавирования (б) от параметров раствора алюмината натрия

Кроме того, при модуле ниже 1,5 и плотности менее $1,2 \mathrm{~cm}^{3}$ вяжущие композиции склонны к вспучиванию. Учитывая это и преследуя цель минимального введения $\mathrm{Na}_{2} \mathrm{O}$, можно сделать вывод о том, что оптимальными характеристиками раствора алюмината натрия являются: щелочной модуль 1,7-1,8 и плотность $1,20-1,25$ г/ $\mathrm{cm}^{3}$ для

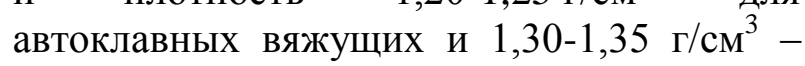
для неавтоклавных.
В нормальных условиях тонкомолотый шамот, затворенный раствором алюмината натрия, не твердеет, что объясняется, вероятно, низкой растворимостью кремнеземистого стекла при обычной температуре [10]. Поэтому в дальнейшем вяжущие на основе шамота, твердеющие при низких температурах, не исследовались.

Известно [10], что растворимость кремнезема в высокощелочной среде, особенно аморфного, резко возрастает при 
температуре выше $150^{\circ} \mathrm{C}$. Вследствие этого в композициях на основе тонкомолотого шамота и алюмината натрия температура тепловлажностного твердения оказывает решающее влияние и на кинетику синтеза щелочных гидроалюмосиликатов. Свидетельством этого являются исследования влияния температуры и длительности тепловлажностной обработки на активность вяжущей композиции из шамота, затворенного раствором алюмината натрия со щелочным модулем 1,73 и плотностью 1,30 г/ $\mathrm{cm}^{3}$. Результаты этих исследований приведены в табл. 3. Их анализ показывает, что увеличение температуры пропаривания с 90 до $99^{\circ} \mathrm{C}$ ведет к незначительному повышению активности вяжущего.

Влияние температуры и длительности тепловлажностного твердения на активность шамотного вяжущего

\begin{tabular}{|c|c|c|c|c|}
\hline \multirow{2}{*}{ Температура, ${ }^{\circ} \mathrm{C}$} & \multicolumn{4}{|c|}{ Предел прочности при сжатии, МПа, при длительности } \\
& \multicolumn{4}{|c|}{ изотермической выдержки в часах } \\
\cline { 2 - 5 } & 2 & 5 & 8 & 24 \\
\hline 90 & 14,5 & 17,7 & 18,0 & 19,5 \\
\hline 99 & 19,0 & 21,5 & 22,5 & 24,8 \\
\hline 150 & 50,8 & 56,9 & 63,0 & 59,5 \\
\hline 173 & 64,5 & 67,0 & 70,5 & 42,0 \\
\hline 193 & 77,0 & 79,2 & 55,6 & 35,0 \\
\hline
\end{tabular}

По сравнению с образцами, пропаренными при $90^{\circ} \mathrm{C}$, подъем температуры автоклавной обработки до $150^{\circ} \mathrm{C}$ при 8 -часовой изотермической выдержке увеличивает прочность затвердевшего вяжущего в 3,5 раза. Дальнейшее повышение температуры автоклавирования хотя и вызывает рост прочности камня вяжущего, но он не такой значительный.

Характерной особенностью тепловлажностного твердения алюминатного шамотного вяжущего является то, что при пропаривании в течение 24 часов изотермического прогрева наблюдается непрерывный рост прочности образцов. При автоклавировании же изменение прочности во времени носит экстремальный характер - после достижения максимума при определенной длительности изотермической выдержки, в дальнейшем происходит сброс прочности. Повышение температуры запаривания сокращает время достижения этого максимума и увеличивает относительное падение прочности. Так, если при температуре 150 и $173^{\circ} \mathrm{C}$ максимум прочности камня вяжущего приходится на 8-часовой период изотермического прогрева, то при температуре $193^{\circ} \mathrm{C}$ - на 5часовой. В первом случае сброс прочности происходит после суточного прогрева, во втором - уже через 8 часов. После 24 часов изотермической выдержки при температуре 150,173 и $193^{\circ} \mathrm{C}$ снижение прочности по отношению к максимально достигнутой составляет $\quad 5,5, \quad 40,4 \quad$ и $\quad 55,8 \%$ соответственно.

Единственным способом повышения огневых свойств шамотного щелочноалюминатного вяжущего является увеличение содержания глинозема за счет введения добавок высокоглиноземистых материалов. Лучшей из использованных высокоглиноземистых добавок является хорошо спеченный муллитокорундовый шамот (или корунд), имеющий низкую водопотребность. Результаты исследования 
влияния его количества на активность вяжущего приведены на рис. 2. Они показывают, что введение до $80 \%$ тонкомолотого муллитокорундового шамота снижает активность вяжущего незначительно. Так, прочность образцов композиции, состоящей из $20 \%$ Новоселицкого и $80 \%$ муллитокорундового шамотов, после пропаривания и автоклавирования остается на уровне соответственно 64 и $78 \%$ прочности образцов, изготовленных с использованием только Новоселицкого шамота.

Вследствие недостатка растворенного кремнезема в жидкой фазе твердение смесей, состоящих из $100 \%$ муллитокорундового шамота, в нормальных условиях не происходит, а при пропаривании эта композиция, затворенная раствором алюмината натрия, вспучивается.

\begin{abstract}
Высокая дисперсность существенно ускоряет процессы растворения микрокремнезема в растворе алюмината натрия и синтез гидроалюмосиликатов уже при нормальной температуре.
\end{abstract} Свидетельством этого являются результаты исследований, приведенные в табл. 4 и 5. Их анализ показывает, что независимо от содержания глинозема в тонкомолотом алюмосиликатном наполнителе добавление к нему от 5 до $40 \%$ аморфного микрокремнезема вызывает непрерывный рост прочностных показателей камня вяжущих после твердения в нормальных условиях, при пропаривании и последующей сушке. Однако активность вяжущих нормального твердения остается невысокой, 5,2-25,7 МПа, возрастая до 17,9-63,8 после пропаривания.

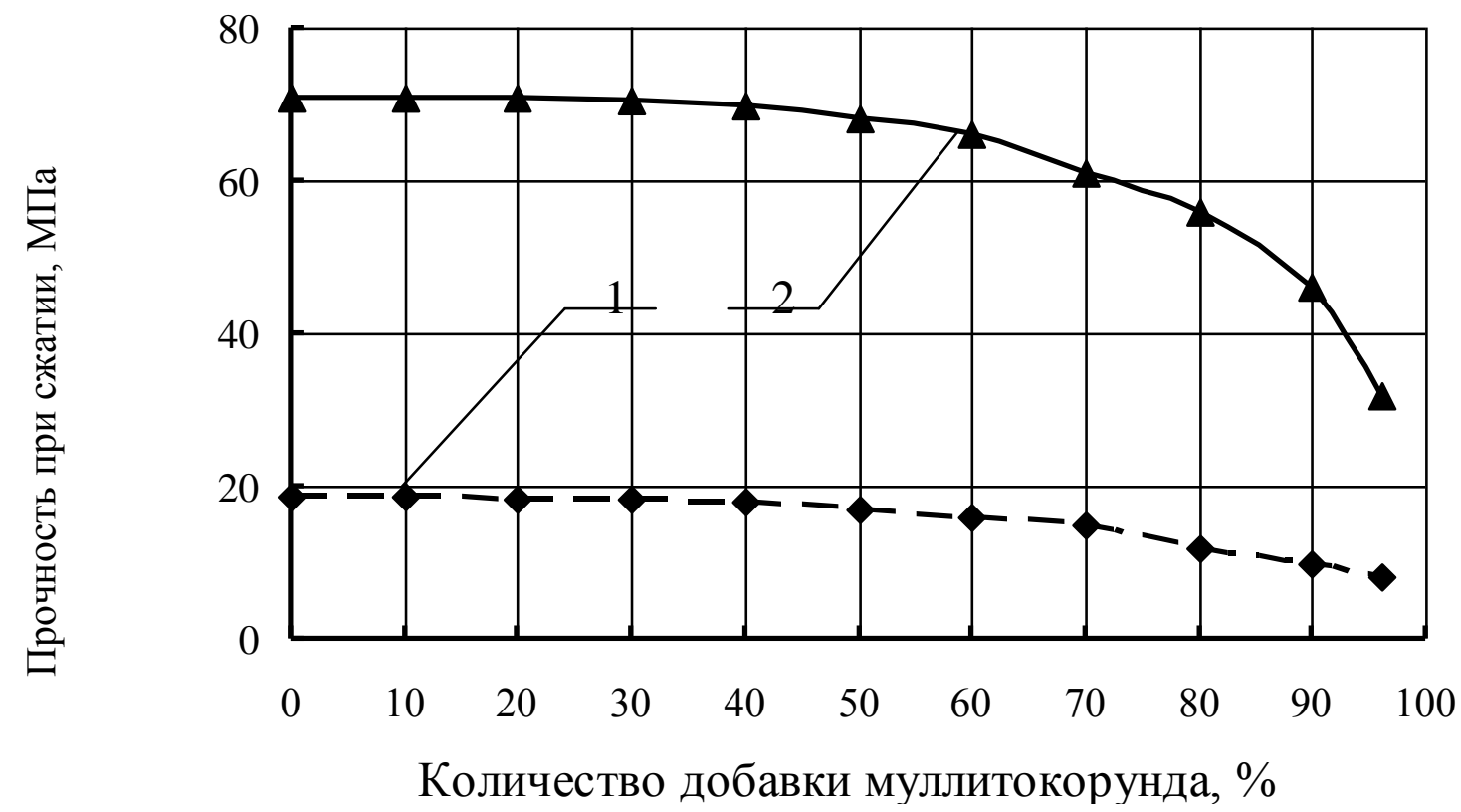

Рис. 2. Влияние условий твердения и количества добавки тонкомолотого муллитокоруда на активность шамотного вяжущего на алюминате натрия:

1 - пропаривание;

2 - автоклавирование 
Таблица 4

Влияние содержания микрокремнезема и вида наполнителей на прочность (Rcж.) камня

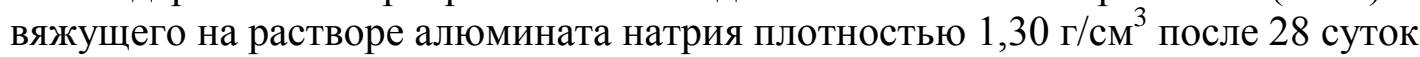
нормального твердения (числитель) и последующей сушки (знаменатель)

\begin{tabular}{|c|c|c|c|c|c|c|c|c|}
\hline \multirow{2}{*}{$\begin{array}{c}\text { Вид } \\
\text { наполнителя }\end{array}$} & \multicolumn{8}{|c|}{ Rсж., МПа, при содержании микрокремнезема, \% массы } \\
\hline & 0 & 5 & 10 & 20 & 40 & 60 & 80 & 100 \\
\hline Шамот & 0 & - & $\frac{5,2}{26,2}$ & $\frac{12,3}{52,1}$ & $\frac{18,3}{59,5}$ & $\frac{17,4}{58,2}$ & $\frac{15,0}{48,5}$ & $\frac{10,0}{43,1}$ \\
\hline $\begin{array}{l}\text { Муллито- } \\
\text { корунд }\end{array}$ & 0 & $\frac{6,6}{26,5}$ & $\frac{12,2}{36,5}$ & $\frac{19,6}{54,8}$ & $\frac{23,2}{69,6}$ & - & - & - \\
\hline Корунд & 0 & $\frac{11,0}{32,8}$ & $\frac{17,7}{77,2}$ & $\frac{23,6}{89,8}$ & $\frac{25,7}{90,5}$ & - & - & - \\
\hline
\end{tabular}

Таблица 5

Влияние содержания микрокремнезема и вида наполнителей на прочность (Rcж.)

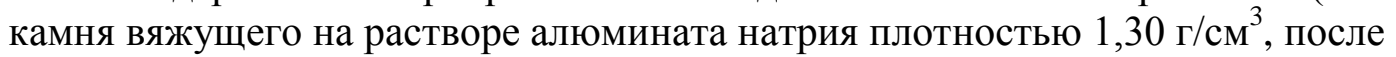
пропаривания (числитель) и последующей сушки (знаменатель)

\begin{tabular}{|c|c|c|c|c|c|c|c|c|}
\hline \multirow{2}{*}{$\begin{array}{c}\text { Вид } \\
\text { наполнителя }\end{array}$} & \multicolumn{8}{|c|}{ Rсж., МПа, при содержании микрокремнезема, \% массы } \\
\hline & 0 & 5 & 10 & 20 & 40 & 60 & 80 & 100 \\
\hline Шамот & 0 & - & $\frac{17,9}{30,5}$ & $\frac{27,8}{54,2}$ & $\frac{36,2}{61,5}$ & $\frac{38,5}{60,4}$ & $\frac{35,7}{50,3}$ & $\frac{29,5}{45,4}$ \\
\hline Муллитокорунд & 0 & $\frac{16,4}{30,0}$ & $\frac{24,7}{40,2}$ & $\underline{38,0}$ & $\frac{56,8}{74,3}$ & - & - & - \\
\hline Корунд & 0 & $\frac{22,2}{26,1}$ & $\frac{34,0}{49,7}$ & $\frac{45,1}{67,4}$ & $\frac{63,8}{77,5}$ & - & - & - \\
\hline
\end{tabular}

Последующая сушка несколько выравнивает показатели прочности камня вяжущих: после нормального твердения и сушки прочность образцов увеличивается до 26,2-76,5 МПа, после пропаривания и сушки - до 30,5-77,5 МПа. Дальнейшее увеличение расхода аморфного микрокремнезема сопровождается снижением прочности. При сушке камень вяжущих дает большую усадку и без наполнителей растрескивается.

Исследовано влияние плотности раствора алюмината натрия на прочностные показатели камня вяжущего состава "аморфный микрокремнезем + наполнитель $=$ $=20+80 "$ (табл. 6). Установлено, что увеличение плотности раствора алюмината натрия с 1,20 до $1,35 \quad \Gamma / \mathrm{cm}^{3}$ вызывает практически прямо пропорциональный рост прочности образцов после пропаривания. Причем с увеличением истинной плотности наполнителей, т.е. при относительном увеличении содержания микрокремнезема по объему в смеси с наполнителем, прочность камня вяжущих при переходе от шамота к муллитокорунду и корунду заметно возрастает. Дальнейшее повышение концентрации раствора ведет к снижению активности вяжущих.

Вяжущие на основе аморфного микрокремнезема способны к длительному твердению в нормальных условиях. В ранние сроки вяжущие с повышенным содержанием микрокремнезема характеризуются более высокой относительной скоростью твердения. Так, при использовании муллитокорундового и корундового наполнителей после 7 суток 
нормального твердения относительная к 28-дневной прочность камня вяжущего с 20 и $10 \%$ микрокремнезема составила соответственно 73-75 и 69-71\%, а после 360 суток $143-144$ и 152-156 \% (табл. 7 ).

Таблица 6

Влияние плотности раствора алюмината натрия на прочность при сжатии (Rсж.) камня вяжущего "микрокремнезем + наполнитель $=20+80$ " после пропаривания (числитель) и последующей сушки (знаменатель)

\begin{tabular}{|c|c|c|c|c|c|}
\hline \multirow{2}{*}{$\begin{array}{l}\text { Вид } \\
\text { наполнителя }\end{array}$} & \multicolumn{5}{|c|}{ 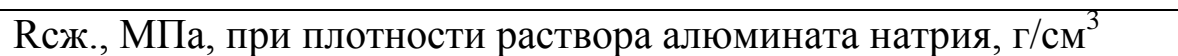 } \\
\hline & 1,20 & 1,25 & 1,30 & 1,35 & 1,40 \\
\hline Шамот & $\frac{12,2}{22,4}$ & $\frac{19,0}{32,3}$ & $\frac{27,4}{38,5}$ & $\frac{32,6}{44,1}$ & $\frac{24,8}{48,4}$ \\
\hline $\begin{array}{l}\text { Муллито- } \\
\text { корунд }\end{array}$ & $\frac{16,5}{38,1}$ & $\frac{25,3}{45,6}$ & $\frac{34,7}{52,0}$ & $\frac{38,6}{55,4}$ & $\frac{32,4}{62,4}$ \\
\hline Корунд & $\frac{23,5}{46,8}$ & $\frac{35,6}{55,4}$ & $\frac{42,6}{65,5}$ & $\frac{49,7}{68,6}$ & $\frac{45,5}{75,0}$ \\
\hline
\end{tabular}

Таблица 7

Влияние содержания алюмосиликатных наполнителей на сроки схватывания и кинетику роста прочности камня вяжущих (Rсж.) нормального твердения на основе алюмината натрия (МПа - числитель, \% - знаменатель)

\begin{tabular}{|l|l|l|l|l|l|l|l|l|l|}
\hline \multirow{2}{*}{$\begin{array}{l}\text { № } \\
\text { пп }\end{array}$} & \multicolumn{3}{|c|}{$\begin{array}{c}\text { Состав порошковой части вяжущих, \% } \\
\text { массы }\end{array}$} & \multicolumn{2}{c|}{$\begin{array}{c}\text { Сроки схва- } \\
\text { тывания, час мин }\end{array}$} & \multicolumn{3}{c|}{$\begin{array}{c}\text { Rсж. при } \\
\text { длительности } \\
\text { твердения, сут }\end{array}$} \\
\cline { 2 - 11 } & шамот & $\begin{array}{c}\text { муллито- } \\
\text { корунд }\end{array}$ & корунд & $\begin{array}{c}\text { микро- } \\
\text { кремнезем }\end{array}$ & начало & конец & 7 & 28 & 360 \\
\hline 1 & 80 & - & - & 20 & $5-30$ & $6-30$ & $\frac{9,2}{68}$ & $\frac{13,6}{100}$ & $\frac{19,2}{141}$ \\
\hline 2 & - & 80 & - & 20 & $5-00$ & $6-15$ & $\frac{18,8}{73}$ & $\frac{25,7}{100}$ & $\frac{36,7}{143}$ \\
\hline 3 & - & 90 & - & 10 & $7-15$ & $8-45$ & $\frac{10,8}{69}$ & $\frac{15,7}{100}$ & $\frac{23,9}{152}$ \\
\hline 4 & - & - & 80 & 20 & $4-15$ & $5-30$ & $\frac{22,3}{75}$ & $\frac{29,7}{100}$ & $\frac{42,8}{144}$ \\
\hline 5 & - & - & 90 & 10 & $6-30$ & $8-00$ & $\frac{12,3}{71}$ & $\frac{17,4}{100}$ & $\frac{27,1}{156}$ \\
\hline
\end{tabular}

Замена обычного шамотного наполнителя с плотностью 2,62 г/ $\mathrm{cm}^{3}$ более тяжелыми муллитокорундом и корундом ведет к снижению нормальной густоты теста вяжущего с $20 \%$ микрокремнезема почти вдвое: с 24,2 \% при использовании шамотного наполнителя до 14,8 и $12,6 \%$ при применении соответственно муллитокорунда и корунда. Расчеты показывают, что при этом в композиции с алюминатом натрия вводится соответственно 4,$04 ; 2,47$ и $2,1 \% \mathrm{Na}_{2} \mathrm{O}$, что позволяет прогнозировать незначительное влияние этого плавня на огневые свойства 
бетонов, особенно с высокоглиноземистыми заполнителями.

\section{Выводы}

1. Оптимизированы составы алюмосиликатных вяжущих на основе композиций

$" 1,7 \mathrm{Na}_{2} \mathrm{O} \cdot \mathrm{Al}_{2} \mathrm{O}_{3}+$ отвердитель + муллитокор ундовый либо корундовый наполнитель". Показно, что при пропаривании и автоклавной обработке в качестве отвердителя раствора алюмината натрия можно применять рядовой шамот, в условиях нормального твердения аморфный микрокремнезем.
2. Исследовано влияние параметров раствора алюмината натрия, соотношений отверждающих компонентов и наполнителей, условий и длительности твердения на нормальную густоту, сроки схватывания и активность вяжущих. На этой основе предложены вяжущие с пределом прочности при сжатии после нормального твердения, пропаривания или автоклавирования в пределах 12,279,2 МПа, а после последующей сушки 22,4-103 МПа.

\section{Список литературы}

1. Шлакощелочные бетоны на мелкозернистых заполнителях [Текст] / под ред. В.Д. Глуховского. - К.: Вища шк., 1981. - 224 с.

2. Krivenko, P. Hydration-Dehydration Structure Formation Processes in Geocements / P. Krivenko, G. Kovalchuk // Proccced Intern. Workshop Geopolymers Binder. - Weimar: 2006. - P. 73-92.

3. Davidovits, J. Geopolymers - inorganic polymeric new materials // Journal of Thermal Analysis. - 1991. - № 37(8). - P. 1633-1656.

4. Будников, П.П. Влияние некоторых факторов на кристаллизацию синтетического цеолита типа «А» [Текст] / П.П. Будников, И.М. Петровых // Журнал прикладной химии. - 1965. - Т. 38. № 1. - С. 10-17.

5. Макеева, Н.С. Свойства автоклавных строительных материалов на основе вулканических стекол [Текст] / Н.С. Макеева, Ю.П. Горлов, М.И. Зейфман // Строительные материалы. - 1985. № 1. - С. 24-25.

6. Стрелов, К.К. Теоретические основы технологии огнеупорных материалов [Текст] / К.К. Стрелов, И.Д. Кащеев. - М.: Металлургия, 1996. - 602 с.

7. Каприелов, С.С. Модифицированные бетоны нового поколения: реальность и перспектива [Текст] / С.С. Каприелов, В.Г. Батраков, А.В. Шейнфельд // Бетон и железобетон. - 1999. - № 6. C. 6-10.

8. Yefremov A.N. Alkaline binders for refractory concretes on the basis of soluble silicates and aluminates of sodium / A.N. Yefremov // 2007-International conference alkali activated Materials-Research, Production and Utilization. - Praha: Zeithamlova Vilena, Ing., 2007. - 717-724.

9. Лайнер, А.И. Производство глинозема [Текст] / А.И. Лайнер. - М.: Металлургиздат, 1961. $-620 \mathrm{c}$.

10. Аваков, В.А. Сравнительная растворимость некоторых модификаций кремнезема [Текст] / В.А. Аваков // Строительные материалы. - 1972. - № 11. - С. 35-36.

11. Вознесенский, В.А. Современные методы оптимизации композиционных материалов [Текст] / В.А. Вознесенский, В.Н. Выровой, В.Е. Керш и др. - К.: Будивельник, 1983. - 144 с.

Ключевые слова: алюмосиликатное огнеупорное вяжущее, шамот, муллитокорунд, корунд, микрокремнезем, алюминат натрия, активность вяжущего. 
Аннотации

Оптимізовані склади алюмосилікатних в'яжучих на основі композицій $" 1,7 \mathrm{Na}_{2} \mathrm{O} \cdot \mathrm{Al}_{2} \mathrm{O}_{3}+$ отвердитель + мулітокорундовий або корундовий наповнювач". Показно, що при пропарюванні і автоклавній обробці як отверджувач розчину алюмінату натрію можна застосовувати рядовий шамот, в умовах нормального твердіння - аморфний мікрокремнезем.

Досліджено вплив параметрів розчину алюмінату натрію, співвідношень отверджуючих компонентів і наповнювачів, умов і тривалості твердіння на нормальну густину, терміни тужавіння і активність в'яжучих. На цій основі запропоновані в'яжучі з межею міцності при стиску після нормального твердіння, пропарювання або автоклавування в межах 12,279,2 МПа, а після подальшої сушки - 22,4-103 МПа.

Оптимизированы составы алюмосиликатных вяжущих на основе композиций $" 1,7 \mathrm{Na}_{2} \mathrm{O} \cdot \mathrm{Al}_{2} \mathrm{O}_{3}+$ отвердитель + муллитокорундовый либо корундовый наполнитель". Показно, что при пропаривании и автоклавной обработке в качестве отвердителя раствора алюмината натрия можно применять рядовой шамот, в условиях нормального твердения аморфный микрокремнезем.

Исследовано влияние параметров раствора алюмината натрия, соотношений отверждающих компонентов и наполнителей, условий и длительности твердения на нормальную густоту, сроки схватывания и активность вяжущих. На этой основе предложены вяжущие с пределом прочности при сжатии после нормального твердения, пропаривания или автоклавирования в пределах 12,2-79,2 МПа, а после последующей сушки - 22,4-103 МПа.

Yefremov A.N. Aluminosilicate binders on the basis of aluminate of sodium // Collection cientific works. - Kharkov: Ukrainian state academy of railway transport, 2013. - Vol. 54. - P.

Compositions of aluminosilicate binders " $1,7 \mathrm{Na}_{2} \mathrm{O} \cdot \mathrm{Al}_{2} \mathrm{O}_{3}+$ hardener + mullito-corund or corundum filler" are optimized. It was rotined, that at the steaming-out and autoclaving as hardening of aluminate of sodium it is possible to apply ordinary shamotte, in the conditions of normal temperatures is amorphous microsilica.

Influencing of parameters of solution of aluminate of sodium, correlations of hardening components-hardeners and fillers, conditions and terms of hardening on the normal density, terms of grasping and durability of binders is investigational. On this basis offered binders with limit of strength at the compression after normal hardening, steaming-out or autoclaving within of 12,279,2 MPa and rough-dry subsequent - 22,4-103 MPa. 